double step formerly used only involves a slight reduction in the clearness of the fringes. The calibrated wedge is omitted and the exact multiple of optical paths is obtained by tilting the larger unit, a method due to Fabry and Buisson ${ }^{16}$.

An $\mathrm{X}$-section gauge, the ends of which are optically parallel, is mounted inside the third étalon, which has to be slightly longer than a metre in order to accommodate the metre gauge. The Brewster fringes, given by three reflections in the intermediate standard and one in the larger unit, are observed in turn through each of the four channels or apertures formed by the Xsection. Thus the mean length $A$ of the largest étalon in wave-length units becomes known. The ends of the $\mathrm{X}$-gauge do not touch the half-silvered étalon surfaces; the path differences $B$ and $C$ between the polished ends of the gauge and the silvered surfaces are determined by means of the circular Hamy fringes using Benoit's fractional part method. The optical length of the gauge is therefore $A-B-C$ wave-lengths, and its mechanical length is also known provided the phase change on reflection at the gauge surfaces is determined by a subsidiary experiment. This has been the primary purpose of the investigation.

In order to obtain the number of waves in the metre, an auxiliary gauge approximately half an inch shorter is employed, together with two further half-inch end gauges at the centres of which fine lines are engraved. If a half-inch gauge is wrung in contact with the auxiliary, a metre end standard is obtained which can be compared directly by interferometric methods with the $\mathrm{X}$-section gauge. When both blocks are wrung, one on each end of the auxiliary, the composite gauge forms a metre line standard which can be compared with the national standard in a line comparator. By taking observations with the blocks contacted in all possible ways, the effects of slight irregularities and differences in the blocks and their bisecting lines are eliminated.

In the determination of the yard, the same étalons were used but the $\mathrm{X}$ - and the auxiliary gauges were 36 and 35.5 in. respectively, so that the differences $B$ and $C$ were therefore much greater.

Reference should also be made to the determination of the yard by Tutton ${ }^{17}$. The method involved the actual counting of the number of fringes in a distance of $\frac{1}{16}$ in. By an ingenious system of multiplication, the number of wavelengths in the yard is determined by means of the Tutton wave-length comparator. The basic unit is, however, too short to yield sufficiently accurate results. This can be seen from the fact that temperature and pressure corrections for the basic unit are negligible, while they are applied to the greater lengths determined in terms of this unit. On the other hand, the accuracy is considerably greater than the one part in fifty thousand which a casual inspection of the method seems to imply.

For the sake of completeness, it might be recorded here that the writer ${ }^{18}$ has proposed an entirely different method whereby the length of a metre gauge in the wave-lengths may be directly obtained from two observations. A suitable reflection echelon is to be used and any errors due to optical multiplication are eliminated.

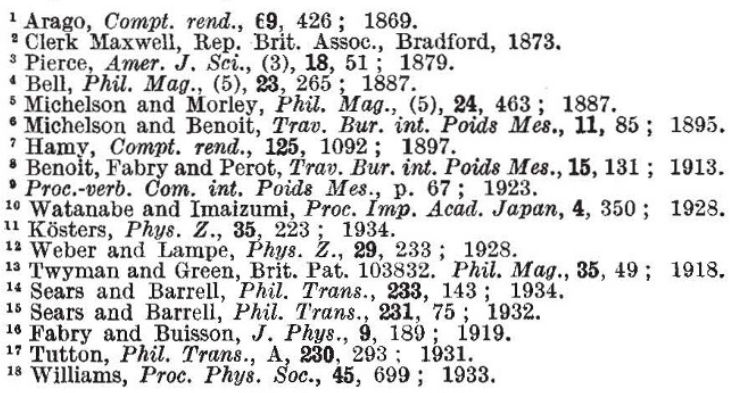
(To be continued.)

\title{
Obituary
}

Prof. M. I. Pupin

$\mathrm{B}^{\mathrm{Y}}$ the death of Michael Idvorsky Pupin in New York on March 12 at the age of seventy-six years, we lose a mathematical physicist who has played an important part in engineering progress since the end of last century. The son of Serbian peasants, he emigrated at the age of sixteen years to New York, where he started to earn his living with only five cents in his pocket. After many struggles, during which he supported himself by manual labour, he gained free tuition at the entrance examination to Columbia University in 1879 and distinguished him. self by winning many prizes both for his studies and at athletics. After graduating, he became a naturalised citizen of the United States.
Pupin was the first holder of the John Tyndall fellowship at Columbia. He elected to complete his training at Cambridge, England, being attracted by the prospect of studying under Clerk Maxwell and learning about his electromagnetic theory of light. Marion Crawford, the novelist, gave him a letter of introduction to Oscar Browning of King's, but he was away on his summer vacation. Pupin also had a letter of introduction to W. D. Niven, a tutor of Trinity College, who asked him what was his object in coming to Cambridge. He replied that he wanted to study under Clerk Maxwell, and was very surprised to learn that Maxwell had been dead for four years.

Before settling down at Cambridge, Pupin went to 
his native village, Idvor, in Hungary, to see his parents. On the way he stayed at Lucerne and was lucky enough to climb to the top of Titlis without accident. When he returned to Cambridge he entered King's College and studied mathematics under Routh. The present writer remembers seeing him there, and was impressed by his striking but un-English appearance. Although he enjoyed Routh's lectures tremendously, Pupin had gone to Cambridge to study physics, and in his interesting autobiography entitled "From Immigrant to Inventor", published in 1923, he says that he thought Prof. J. J. Thomson was too young to teach him much, and he was suspicious of Lord Rayleigh because of his title. Later on, he had the greatest admiration for them both.

After a two months holiday at Corrie in the Isle of Arran, where he read Faraday's "Experimental Researches", Pupin went to the University of Berlin and studied under Helmholtz and Kirchhoff, obtaining a Ph.D. degree. On his return to New York he was appointed to a teaching post at Columbia University, was afterwards appointed adjunct professor of mechanics, and then professor of electro-mechanics in 1901.

In 1896 Pupin discovered secondary $\mathrm{X}$-ray radiation and invented in the same year means for short exposure X-ray photography, by interposing a fluorescent screen before the photographic plate. He invented also improvements in multiplex telegraphy and in methods of tuning for electrical resonance. His most important invention was in connexion with long-distance telephone communication. By means of inductance coils placed at pre-determined intervals of the transmitting line, he greatly extended its range. In almost every country in the world 'Pupin coils' are used, and the enormously rapid develop. ment of long-distance telephony during this century has been due mainly to the use of these coils. His first paper on the subject was published in the Journal of the American Institution of Electrical Engineers of March 22, 1899.

Although an American citizen, Pupin will long be remembered by thousands of his former countrymen in Serbia-now Yugoslavia. He founded the Serbian House in New York, and fathered and cared for thousands of poor immigrants. He gave princely contributions to the Serbian Red Cross, to refugee funds and to many others, and his ample fortune, made mainly from his tele-communication inventions, was sorely diminished. At Columbia University he was much esteemed and held in affection by the students. He was a member of the executive committee of the National Research Council, a fellow of many scientific societies and an honorary doctor of Columbia and Johns Hopkins Universities.

A. $R$.

\section{Prof. H. A. GILes}

WE regret to record the death on February 13 of Prof. H. A. Giles, formerly professor of Chinese in the University of Cambridge. Herbert Allen Giles was born on December 8, 1845, the son of Dr. John Allen Giles, well-known to many generations of students of the classies as a translator. He was educated at Charterhouse and in 1867 joined the consular service in China, being appointed to Tientsin after a probationary year at Peking. He retired from the service in 1893, returning to England, and in 1897 was appointed professor of Chinese at Cambridge. He held this chair until 1932 when he retired, having done much to foster the study of the Chinese language in the University, and secured its recognition in the 'Little go' in place of Latin or Greek for natives of Asia.

Giles laid the foundations of his scholarship in Chinese during his probationary year in Peking. Within a few years of his appointment to Tientsin, his knowledge of China had progressed so far as to enable him to write with authority on many sides of Chinese life and culture in the Celestial Empire. $\mathrm{He}$ had also begun work on his monumental ChineseEnglish dictionary. This indeed was to prove his magnum opus. It appeared in parts and in this form was completed in 1892. A new edition, revised and enlarged, appeared in 1912. It won him world-wide recognition as the first European authority on the Chinese language, and in 1911 was awarded the Prix St. Julien of the French Academy. Its preeminence in scholarship, however, should not be allowed to obscure the fact that Giles's knowledge of every side of Chinese life and culture was profound. Nowhere, perhaps, does this come out more clearly than in Giles's lighter works, and his "Strange Stories from a Chinese Studio" and "Quips from a Chinese Jest Book", no less informative than they are amusing, with their instructive notes and comments, might well serve as an introduction to most aspects of the many-sided Chinese mentality.

From 1870 onward, Giles was busily engaged, in such leisure as his consular duties afforded, in studying and in writing on the life, art, religion, language and history of the Chinese people. A long list of substantial and authoritative works stands to his credit, of which the best known, next to his dictionary, is "A Chinese Biographical Dictionary". His achievement was recognised by many honours, among which may be mentioned the Order of Chia Ho, conferred by the Chinese Government, the award of the triennial gold medal of the Royal Asiatic Society and honorary degrees from the Universities of Oxford and Aberdeen.

WE regret to announce the following deaths :

Prof. J. J. R. Macleod, F.R.S., regius professor of physiology in the University of Aberdeen, formerly professor of physiology in the University of Toronto, on March 16, aged fifty-eight years.

Prof. B. M. Wilson, professor of mathematics in University College, Dundee, formerly lecturer in pure mathematics in the University of Liverpool, on March 18, aged thirty-eight years.

Major-Gen. Sir Richard M. Ruck, of the Royal Engineers, known for his scientific work in submarine mining, chairman of Council of the Royal Aeronautical Society from 1912 until 1919, on March 18, aged eighty-three years. 